\title{
$\mathbf{D a s}$ \\ Bayeríde Fagdge/ek \\ vom 30. März 1850
}

Mit den Geletzen

úber den Erjat des wild/đadens

und

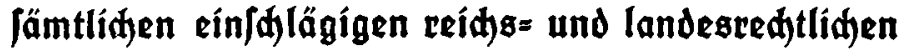

Beftímmungen

crläutert von

Dr. jur. et rer. pol. Albert $\mathfrak{B e h r}$

Candgeridistat in Regensburg

2. neubearbeitete 2 luflage

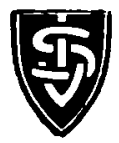

1928

Muänden, Berlin und Eeipzíg

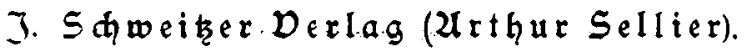




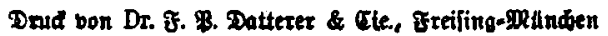
Printed in Germany. 